\section{Styrene-lined and Copper-coated Containers Affect Production and Landscape Establishment of Red Maple}

\author{
Thomas J. Brass ${ }^{1}$, Gary J. Keever ${ }^{2}$, D. Joseph Eakes ${ }^{3}$, and \\ Charles H. Gilliam² \\ Department of Horticulture, Auburn University, AL 36849
}

Additional index words. Acer rubrum, container production, copper hydroxide, root regeneration, woody ornamentals

\begin{abstract}
Growth response of two red maple cultivars (Acer rubrum L. 'October Glory' and 'Northwood') to styrene lining or copper hydroxide coating of 23.3-liter black plastic containers was evaluated. After the first growing season, plants were left in their original container, repotted into 51.2-liter nontreated containers, or transplanted into the landscape. Copper hydroxide effectively reduced circling of roots of both cultivars at the medium-container interface during the first year of production, but was less effective during the second growing season. Repotting from copper-treated containers into 51.2liter containers or transplanting into the landscape resulted in more fibrous root development and enhanced root regeneration outside the original rootball relative to transplanting from nontreated containers. However, when copper hydroxide was applied to styrene lining, root regeneration after transplanting was reduced. Roots of plants grown in styrene-lined containers covered the medium-container interface more thoroughly than those in nonlined containers, but height, trunk diameter, and root regeneration were similar. 'October Glory' had a larger trunk diameter, more branching, and better root regeneration than 'Northwood'.
\end{abstract}

Container production of nursery crops offers numerous advantages over field production (Whitcomb, 1984). However, densely matted, kinked, and downward-deflected surface roots are common in vigorous plant species grown in containers (Ruter, 1994) or plants held too long in a given size container (Whitcomb and Williams, 1985). Transplanting container-grown stock with poor root development results in poor transplant establishment (Arnold and Struve, 1989; Struve, 1993), increased trunk breakage, poor mechanical stability (Nichols and Alm, 1983; Stone and Norberg, 1978), and reduced shoot growth (Arnold and Struve, 1989; Arnold et al., 1993).

An altered container design has been evaluated as one strategy for limiting root circling and malformation; however, modification of root growth has been inconsistent (Appleton, 1989; Whitcomb, 1981; Whitcomb and Williams, 1985). More positive results have been achieved by coating the interior wall of containers with various copper compounds. Copper inhibits root tip growth, increases secondary root branching, reduces root circling, im-

Received for publication 11 Sept. 1995. Accepted for publication 15 Mar. 1996. Supported in part by the Horticultural Research Institute, Washington, D.C.; Griffin Corp., Valdosta, Ga.; J. Frank Schmidt \& Son Co., Boring, Ore.; and the Dart Container Corp., Leola, Pa. The cost of publishing this paper was defrayed in part by the payment of page charges. Under postal regulations, this paper therefore must be hereby marked advertisement solely to indicate this fact.

${ }^{1}$ Graduate Research Assistant.

${ }^{2}$ Professor.

${ }^{3}$ Associate Professor

HortScience, Vol. 31(3), June 1996 production. The objective of our study was to compare two bareroot red maple cultivars from divergent geographical provenances to determine the effects of copper-coated and styrenelined containers on root and shoot growth during production and landscape establishment.

\section{Materials and Methods}

Acer rubrum 'October Glory' and 'Northwood' were selected for study based on growth and fall color performance in the southeastern United States (Williams et al., 1993). On 13 Mar. 1993, a $2 \times 2 \times 2$ factorial experiment was established with treatments that included all combinations of the two cultivars, +/- styrene lining, and +/- copper coating [+Cu or $-\mathrm{Cu} ; 100 \mathrm{~g} \mathrm{Cu}(\mathrm{OH})_{2} /$ liter of latex base (Spin Out, Griffin Corp., Valdosta, Ga.)]. Styrene lining (2.6 mm thick) (Dart Industries, Leola, Pa.) was cut and inserted to cover pot sidewalls. Copper hydroxide was applied with an electric paint sprayer (Wagner Spray Tech Corp., Minneapolis) directly to the containers' interior surfaces or directly to the styrene, which was later inserted into the container. Copper hydroxide also was applied to the bottom of containers receiving the styrene and copper treatments. Dormant 1.5-m-tall $(\approx 1.3$ $\mathrm{cm}$ diameter $15 \mathrm{~cm}$ above the medium surface) whips of each cultivar were planted in 23.3liter, injection-molded black plastic containers with a 4 pinebark : 1 sand (v/v) medium amended with $\left(\mathrm{kg} \cdot \mathrm{m}^{-3}\right) 6.417 \mathrm{~N}-3 \mathrm{P}-10 \mathrm{~K}$ Osmocote (Scotts Co., Marysville, Ohio), 0.7 Micromax (Scotts Co.), and 2.3 dolomitic limestone.

Plants were subsequently spaced $0.9 \mathrm{~m}$ within rows and $1.2 \mathrm{~m}$ between rows on a gravel container bed in direct sunlight. Plants were irrigated with an overhead irrigation system, as needed. Treatments were arranged in a completely randomized design with 16 singleplant replications.

Plant height and trunk diameter $15 \mathrm{~cm}$ above the medium surface were recorded in July 1993 for all plants. In Nov. 1993, plant height, trunk diameter, percentage of the medium-container interface covered with roots (\% MCI), and root deflection were measured. The $\%$ MCI was estimated independently by two investigators. Root deflection was rated on a scale of 0 to $2: 0=$ roots $>2.5 \mathrm{~cm}$ long (no restriction of root elongation); $1=0.6 \mathrm{~cm}<$ root length $<2.5 \mathrm{~cm}$; and $2=$ roots $<0.6 \mathrm{~cm}$ long (little to no root elongation), according to Arnold et al. (1993). Rootballs of four plants per treatment were subsampled for root dry weight determinations in Dec. 1993. Pieshaped sections ( $5.1 \mathrm{~cm}$ wide and $5.1 \mathrm{~cm}$ deep) were removed from each quadrant with a saber saw using a 7.6-cm wood cutting blade. Roots from these sections were isolated, dried, and weighed.

The four replications subsampled in Dec. 1993 were left in their original containers during 1994 to determine treatment effects when top growth was disproportionately great relative to container size. This experimental procedure also allowed us to determine 
copper's residual effect on root suppression, and the growth and quality of plant material held over in its original container. Plants were topdressed with $150 \mathrm{~g}$ Osmocote $17 \mathrm{~N}-3 \mathrm{P}-$ $10 \mathrm{~K} /$ pot in Apr. 1994. Plant height, trunk diameter, and \% MCI were determined in May, July, and Nov. 1994.

In Dec. 1993, six replications of each treatment were repotted into 51.2-liter, nontreated black containers with the medium previously described. Surface roots were not disturbed during repotting to determine treatment effects on root regeneration outside the original rootball. Plants were placed in a completely randomized design and were spaced and watered as previously described. Plant height and trunk diameter of all plants were measured in May 1994. In May and Oct. 1994, \% MCI and dry weight of roots outside the original rootball were determined for three replications per treatment. Height and trunk diameter were measured on the remaining three replications in July and Oct. 1994.

In Jan. 1994, six replications of each treatment were planted in a Marvyn loamy sand soil (fine-loamy, siliceous, thermic Typic Hapludults). Plants were spaced $1.5 \mathrm{~m}$ within rows and $1.5 \mathrm{~m}$ between rows in a completely randomized design in augured holes $0.9 \mathrm{~m}$ across and $0.6 \mathrm{~m}$ deep. Based on soil test recommendations, $67.2 \mathrm{~kg} \mathrm{~N} / \mathrm{ha}$ and $55.8 \mathrm{~kg}$ $\mathrm{K} /$ ha from $15 \mathrm{~N}-0 \mathrm{P}-12.5 \mathrm{~K}$ were preplantincorporated in Jan. 1994 and $67.2 \mathrm{~kg} \mathrm{~N} / \mathrm{ha}$ from 34N-0P-0K was broadcast in May 1994. Plants were watered immediately after transplanting and overhead-irrigated as needed. Height and trunk diameter were measured in July and Dec. 1994. In December, all visible roots ( $\geq 1 \mathrm{~mm}$ long) extending beyond the original rootball were harvested for dry-weight determination. Plants were excavated with a backhoe using a 0.9-m-wide $\times 0.9$-m-deep bucket, and roots were washed free of soil. Roots left after excavation were removed manually, washed of soil, and used for dryweight determination. All data were subjected to an analysis of variance.

\section{Results and Discussion}

Plants grown in 23.3-liter containers during 1993. Neither styrene nor copper affected height or trunk diameter of either cultivar (data not shown); however, there was a cultivar $\times$ styrene interaction for change in plant height between summer and fall measurements. 'October Glory' grown in pots with styrene grew more in height than plants in containers without styrene (34.8 vs. $27.4 \mathrm{~cm})$; while statistically significant $(P \leq 0.05)$, the $7.4-\mathrm{cm}$ difference may not be economically important. Height increase for 'Northwood' was unaffected by styrene (data not shown). 'October Glory' grew more in height than 'Northwood', regardless of styrene treatment ( 34.8 vs. $15.8 \mathrm{~cm}$ in lined containers; 27.4 vs. $18.3 \mathrm{~cm}$ in nonlined containers). Copper treatment did not affect height or trunk diameter at either sampling date (data not shown). Previous studies indicated varied plant response to copper, with an increase (Arnold and Struve,
1993; Beeson and Newton, 1992), decrease (Beeson and Newton, 1992; Ruter, 1994), or no change (Beeson and Newton, 1992) in shoot growth reported. At midseason and at the end of the season, 'October Glory' had thicker trunks than 'Northwood' (Table 1). 'October Glory' was taller than 'Northwood' (263 vs. $247 \mathrm{~cm}$ ) by November. In addition, 'October Glory' had noticeably heavier branching.

The $\%$ MCI was affected by a copper $\times$ styrene interaction. Copper-treated containers effectively controlled surface root development, regardless of styrene treatment $(83.0 \%$ vs. $19.0 \%$ in lined containers; $64.5 \%$ vs. $17.4 \%$ in nonlined containers). In the absence of copper, \% MCI was higher for styrene-lined than for nonlined containers ( $83.0 \%$ vs. $64.5 \%$ ), which may reflect lower temperatures resulting in less root damage at the mediumcontainer interface (Brass et al., 1994). However, in the presence of copper, surface root development was greatly reduced and styrene had no effect. Chemical control of root deflection was achieved for both cultivars with or without styrene lining (rating of 0.7 vs. 0.0 for 'October Glory'; 1.1 vs. 0.4 for 'Northwood'), even though control of root deflection was greater for 'Northwood'. As reported by Ruter (1994), copper treatment also resulted in less control of root growth, as judged visually, for both cultivars near the bottom of the container. At the end of the growing season, \% MCI was higher for 'October Glory' (53\%) than for 'Northwood' (39\%). This difference in cultivar response was similar to that observed with shoot elongation and trunk diameter.

There were no styrene or copper effects on dry weight of roots removed from the pieshaped quadrants in Nov. 1993 (data not shown). Root systems were visibly more fibrous within the rootball after the primary roots had come in contact with copper-treated surfaces. This observation agrees with an earlier study by Arnold and Struve (1993). Because higher \% MCI was present for plants grown in $-\mathrm{Cu}$ containers, and visually more lateral root development within the rootball was present for plants grown in $+\mathrm{Cu}$ containers, the pie-shaped quadrants may have offset differences in root dry weight. Samples quantifying distribution of root growth and a larger sample size might have resulted in a larger difference. Dry weight of roots from the quadrants was $>2.5$ times higher for 'October Glory' $(9.8 \mathrm{~g})$ than for 'Northwood' ( $3.5 \mathrm{~g})$.

Plants grown in 23.3-liter containers during 1994. Differences in trunk diameter between 'October Glory' and 'Northwood' were similar to those in 1993 (Table 1). Cultivar plant heights were similar, but branching of 'October Glory', as judged visually, was more extensive than that of 'Northwood', regardless of copper or styrene treatment. Styrenelined containers had no effect on height (data not shown) or trunk diameter when plants were left in 23.3-liter containers during the second year (data not shown), while coppertreated containers resulted in thicker trunks by May 1994, with no difference thereafter (Table 1).
The $\%$ MCI was affected by cultivar $x$ styrene and cultivar $\times$ copper interactions during the second growing season (Table 2). Both cultivars had higher \% MCI in styrene-lined than in nonlined containers, possibly due to lower surface temperatures in lined containers (Brass et al., 1994). 'October Glory' had a higher \% MCI in nonlined containers than 'Northwood', while \% MCI was similar in styrene-lined containers. Both cultivars had a higher \% $\mathrm{MCI}$ in $-\mathrm{Cu}$ containers than in $+\mathrm{Cu}$ containers (Table 2). Copper was less effective in inhibiting circling roots during the second growing season $(60.4 \%,+\mathrm{Cu}$ vs. $81.3 \%$, $-\mathrm{Cu})$ as compared to the first growing season $(18.1 \%,+\mathrm{Cu}$ vs. $73.7 \%,-\mathrm{Cu})$. Root circling along the container wall for plants in $+\mathrm{Cu}$ containers likely would not interfere with transplantibility. However, as observed for some red maples grown in $+\mathrm{Cu}$ containers, roots began to emerge from the top of the rootball and circle around the stem, requiring extensive pruning at time of transplanting. Due to the plants' extensive root systems, the medium's ability to absorb and retain water was minimal, and as a result, plants tended to dry quickly. This condition, along with 'October Glory' becoming top heavy, resulted in a need for staking plants to prevent toppling.

Plants repotted into 51.2-liter containers, 1994. Neither styrene nor copper treatments affected plant height in 1994. However in July and Oct. 1994, trunks of plants originally grown in 23.3-liter $+\mathrm{Cu}$ containers grew less than those never exposed to copper (Table 1). These results support previous studies indicating less trunk diameter growth of red maples during the first year after releasing them from +Cu containers (Struve, 1993). 'October Glory' still had thicker trunks (Table 1), more branching, and denser canopies at the end of the 1994 growing season than did 'Northwood'. Repotting plants into larger containers resulted in a greater height increase $(13.2 \mathrm{~cm}$, 'October Glory'; $26.3 \mathrm{~cm}$, 'Northwood'), and larger trunk diameter (Table 1) than leaving them in their original containers (23.3 liters) $(P \leq$ 0.01 ).

No differences in \% MCI (May or Oct. 1994) or root dry weight (May 1994) were evident for either cultivar previously grown in styrene- or copper-treated containers (data not shown), possibly due to the small sample ( $\mathrm{n}=$ 3 ). Dry weight of roots extending beyond the original rootball for both cultivars was influenced by a styrene $\mathrm{x}$ copper interaction in Oct. 1994 (Table 3). In the presence of copper, root dry weight was higher for plants previously grown in nonlined containers than for those with styrene lining, apparently due to an adverse effect of the styrene-copper combination. In the absence of copper, styrene lining had no effect on root dry weight. Root dry weights in containers originally lined with styrene were less for plants released from copper, while in the absence of styrene, root dry weights were higher for plants previously grown in $+\mathrm{Cu}$ containers. After removing root outgrowth from the original rootball, there was a noticeable difference in the original rootball's integrity and root density. When 
Table 1. Trunk diameter of 'October Glory' and 'Northwood' red maple grown in 23.3-liter containers coated with $\mathrm{Cu}(\mathrm{OH})_{2}$ and transplanted into 51.2-liter nontreated containers or into the landscape.

\begin{tabular}{|c|c|c|c|c|c|c|c|c|c|c|}
\hline \multirow[b]{4}{*}{ Variable $^{\mathrm{x}}$} & \multicolumn{10}{|c|}{ Trunk diam $(\mathrm{cm})$} \\
\hline & \multicolumn{2}{|c|}{ 23.3-liter pots } & \multicolumn{3}{|c|}{ 23.3-liter pots } & \multicolumn{3}{|c|}{ 51.2-liter pots ${ }^{2}$} & \multicolumn{2}{|c|}{$\begin{array}{l}\text { Following } \\
\text { transplanting }\end{array}$} \\
\hline & \multicolumn{2}{|c|}{1993} & \multicolumn{3}{|c|}{1994} & \multicolumn{3}{|c|}{1994} & \multicolumn{2}{|c|}{1994} \\
\hline & July & November & May & July & November & May & July & October & July & December \\
\hline \multicolumn{11}{|l|}{$\overline{\text { Cultivar }}$} \\
\hline October Glory & $2.1 \mathrm{a}^{\mathrm{w}}$ & $2.8 \mathrm{a}$ & $3.0 \mathrm{a}$ & $3.1 \mathrm{a}$ & $3.1 \mathrm{a}$ & $3.2 \mathrm{a}$ & $3.4 \mathrm{a}$ & $4.6 \mathrm{a}$ & $3.3 \mathrm{a}$ & $3.5 \mathrm{a}$ \\
\hline Northwood & $1.8 \mathrm{~b}$ & $2.1 \mathrm{~b}$ & $2.4 \mathrm{~b}$ & $2.7 \mathrm{~b}$ & $2.9 \mathrm{~b}$ & $2.7 \mathrm{~b}$ & $3.1 \mathrm{~b}$ & $3.4 \mathrm{~b}$ & $2.8 \mathrm{~b}$ & $3.2 \mathrm{~b}$ \\
\hline \multicolumn{11}{|l|}{ Copper } \\
\hline+ & $2.1 \mathrm{a}$ & $2.7 \mathrm{a}$ & $2.9 \mathrm{a}$ & $2.9 \mathrm{a}$ & $3.0 \mathrm{a}$ & $2.8 \mathrm{a}$ & $3.0 \mathrm{~b}$ & $3.9 \mathrm{~b}$ & $3.1 \mathrm{a}$ & $3.4 \mathrm{a}$ \\
\hline - & $2.0 \mathrm{a}$ & $2.5 \mathrm{a}$ & $2.6 \mathrm{~b}$ & $2.7 \mathrm{a}$ & $2.9 \mathrm{a}$ & $2.8 \mathrm{a}$ & $3.4 \mathrm{a}$ & $4.1 \mathrm{a}$ & $3.0 \mathrm{a}$ & $3.3 \mathrm{a}$ \\
\hline
\end{tabular}

${ }^{2}$ In Dec. 1993, six replications of 23.3-liter pots per treatment were repotted into 51.2-liter containers.

yIn Jan. 1994, six replications of 23.3-liter pots per treatment were transplanted into the landscape.

${ }^{x}$ Interactions nonsignificant.

"Mean separation of main effects within columns by analysis of variance, $P \leq 0.05$.

Table 2. Percentage of medium-container interface covered with roots in 23.3-liter containers, Nov. 1994.

\begin{tabular}{|c|c|c|c|c|}
\hline \multirow[b]{3}{*}{ Cultivar } & \multicolumn{4}{|c|}{ Surface covered with roots $(\%)$} \\
\hline & \multicolumn{2}{|c|}{ Styrene lining } & \multicolumn{2}{|c|}{ Copper coating } \\
\hline & + & - & + & - \\
\hline October Glory & $80.7 \mathrm{aA}^{\mathrm{z}}$ & $63.4 \mathrm{aB}$ & $57.2 \mathrm{aB}$ & $86.8 \mathrm{aA}$ \\
\hline Northwood & $75.6 \mathrm{aA}$ & $38.8 \mathrm{bB}$ & $55.8 \mathrm{aA}$ & $60.0 \mathrm{bB}$ \\
\hline
\end{tabular}

${ }^{2}$ Mean separation within columns (lowercase) and rows (uppercase) by analysis of variance, $P \leq 0.05$.

Table 3. Dry weight of red maple roots outside the original rootball.

\begin{tabular}{lccccc}
\hline \hline & \multicolumn{3}{c}{ Dry wt (g) } \\
\cline { 2 - 5 } & \multicolumn{2}{c}{$\begin{array}{c}\text { In 51.2-liter containers } \\
\text { (Oct. 1994) } \\
\text { styrene lining }\end{array}$} & & \multicolumn{2}{c}{$\begin{array}{c}\text { Following transplanting } \\
\text { (Dec. 1994) } \\
\text { styrene lining }\end{array}$} \\
\cline { 2 - 3 } Copper & + & - & & + & - \\
\hline+ & $167 \mathrm{bB}^{\mathrm{x}}$ & $223 \mathrm{aA}$ & & $177 \mathrm{aB}$ & $258 \mathrm{aA}$ \\
- & $194 \mathrm{aA}$ & $181 \mathrm{bA}$ & & $186 \mathrm{aA}$ & $157 \mathrm{bA}$ \\
\hline
\end{tabular}

${ }^{2}$ In Dec. 1993, six replications per treatment were repotted from 23.3-liter containers into 51.2-liter containers.

y'In Jan. 1994, six replications per treatment were transplanted from 23.3-liter containers into the landscape. ${ }^{x}$ Mean separation within columns (lowercase) and rows (uppercase) by analysis of variance, $P \leq 0.05$.

plants were previously grown in $+\mathrm{Cu}$ containers, preservation of the original rootball was maintained by the emergence of a dense network of lateral roots protruding from the rootball, which may account for the increased transplant survival and regrowth previously reported (Struve, 1993). In -Cu containers, rootballs tended to fall apart as a result of less root distribution within the original rootball.

The \% MCI (54.6\%, 'October Glory' vs. $34.6 \%$, 'Northwood') and root dry weight (27.6 g, 'October Glory' vs. 5.7 g, 'Northwood') differed for the cultivars in May 1994; but in October, dry weight of newly regenerated roots was higher for 'October Glory' than for 'Northwood' (115.8 g).

Landscape establishment. Both cultivars exhibited symptoms of transplant shock. There was little to moderate shoot growth during the growing season, but no leaf drop or stem dieback. Height and trunk diameter for both cultivars previously grown in styrene- or copper-treated containers were not influenced by treatment once planted into the landscape (data not shown). Struve (1993) and Arnold and Struve (1984) reported that plants grew little during the initial season following transplanting and differential responses to copper were most apparent during the second or third growing season. 'October Glory' maples were taller than 'Northwood' 7 (263 vs. $251 \mathrm{~cm})$ and 12 months (266 vs. $253 \mathrm{~cm}$ ) after transplanting, and also had thicker trunks (Table 1).

Regenerated root dry weight was influenced by a cultivar $\times$ copper interaction. 'October Glory' had higher root dry weights than 'Northwood', regardless of copper treatment (+Cu, 288 vs. $125 \mathrm{~g} ;-\mathrm{Cu}, 209$ vs. $117 \mathrm{~g}$ ). Additionally, 'October Glory' trees previously grown in $+\mathrm{Cu}$ containers had a higher root dry weight than those grown in $-\mathrm{Cu}$ containers $(288 \mathrm{~g},+\mathrm{Cu}$ vs. $209,-\mathrm{Cu})$. 'Northwood' had similar root dry weights, regardless of prior copper treatment $(125 \mathrm{~g},+\mathrm{Cu}$ vs. $117 \mathrm{~g},-\mathrm{Cu})$. Before transplanting into the landscape, 'October Glory' had a higher \% MCI (circling roots) compared to 'Northwood' in - Cu containers (Table 2). This condition may explain the tremendous difference in root dry weight of 'October Glory' after transplanting from $+\mathrm{Cu}$ containers compared to those grown in -Cu containers, and why copper treatment had no effect on 'Northwood', i.e., due to limited root circling before transplanting.

Regenerated root dry weight, i.e., that after transplanting, also was affected by a copper $\times$ styrene interaction (Table 3 ). When containers were treated with copper, plants in styrenelined containers produced less root dry weight than those in nonlined containers, while in the absence of copper, styrene lining had no effect on root dry weight. After transplanting, root dry weight for plants previously grown in nonlined containers was higher in $+\mathrm{Cu}$ containers than for plants grown in - $\mathrm{Cu}$ containers. These results are similar to those for plants that had been transferred to 51.2-liter containers.

This study indicates that the application of copper hydroxide coating to containers can effectively reduce circling of roots along the medium-container interface of bareroot, potted red maple trees. Copper treatment enhanced root regeneration after repotting into larger containers or transplanting into the landscape. The application of copper hydroxide to containers with styrene lining resulted in less root regeneration after transplanting. Copper treatment had no effect on shoot length or trunk diameter of plants grown in containers or transplanted into the landscape during the first year. Styrene lining did not affect shoot length, trunk diameter, or root dry weight of red maple, but higher \% MCI was fostered. Plant growth was positively influenced by repotting into larger containers, and 'October Glory' performed better than 'Northwood', regardless of styrene or copper treatment.

\section{Literature Cited}

Appleton, B.L. 1989. Evaluation of nursery container designs for minimization or prevention of root circling. J. Environ. Hort. 7:59-61.

Arnold, M.A., D.L. Airhart, and W.E. Davis. 1993. Cupric hydroxide-treated containers affect growth and flowering of annual and perennial bedding plants. J. Environ. Hort. 11:106-110.

Arnold, M.A. and D.K. Struve. 1989. Growing green ash and red oak in $\mathrm{CuCO}_{3}$-treated containers increases root regeneration and shoot growth following transplant. J. Amer. Soc. Hort. Sci. 114:402-406.

Arnold, M.A. and D.K. Struve. 1993. Root distribution and mineral uptake of coarse-rooted trees grown in cupric-hydroxide treated containers. HortScience 28:988-992.

Beeson, R.C., Jr., and R. Newton. 1992. Shoot and root responses of eighteen southeastern woody landscape species grown in cupric hydroxidetreated containers. J. Environ. Hort. 10:214 217.

Benson, S.D. (ed.). 1992. Polystyrene insulators. Amer. Nurseryman 171:57, 60.

Brass, T.J., G.J. Keever, C.H. Gilliam, and D.J. Eakes. 1994. Styrene-lined and copper-coated pots affect maple growth. HortScience 29:730. (Abstr.) 
Brown, W.L. 1984. Effects of container, spacing, and time of spacing on growth of selected plants. Proc. Southern Nurserymen's Assn. Res. Conf. 29:80-83.

Fretz, T.A. 1971. Influence of physical conditions on summer temperatures in nursery containers. HortScience 6:400-401.

Graves, W.R., M.N. Dana, and R.J. Joly. 1989. Root-zone temperature affects water status and growth of red maple. J. Amer. Soc. Hort. Sci. 114:406-410

Havis, J.R. 1976. Root hardiness of woody ornamentals. HortScience 11:385-386.

Ingram, D.L. and D.W. Buchanan. 1981. Measurement of direct heat injury of roots of three woody plants. HortScience 16:769-770.

Ingram, D.L. and C.R. Johnson. 1981. Influence of orientation, spacing and placement patterns of production container on 'Formosa' azalea growth. Proc. Southern Nurserymen's Assn. Res. Conf. 26.20-21.

Ingram, D.L., C.A. Martin, and J.M. Ruter. 1989. Effect of heat stress on container-grown plants. Comb. Proc. Intl. Plant Prop. Soc. 39:348-353.

Johnson, C.R. and D.L. Ingram. 1984. Pittosporum tobira response to container medium temperatures. HortScience 26:370-371.

Keever, G.J. and G.S. Cobb. 1985. Irrigation scheduling effects on container media and canopy temperatures and growth of 'Hershey's Red' azalea. HortScience 20:921-923.

Krieg, R.J. and W.T. Witte. 1993. Efficacy of a cupric hydroxide/latex paint formulation for root pruning 41 species of containerized nursery stock. Proc. Southern Nurserymen's Assn. Res. Conf. 38:129-131.

Laiche, A.J. 1985. Effect of time of spacing on the growth of container-grown Ilex cornuta 'Dwarf Burford' Lindl. and Paxt., and Pittosporum tobira, Thumb. J. Environ. Hort. 3:22-24.

Martin, C.A. and D.L. Ingram. 1991. Root growth of southern magnolia following exposure to high root-zone temperatures. HortScience 26:370371

Newman, S.E. and F.T. Davies, Jr. 1988. High rootzone temperatures, mycorrhizal fungi, water relations, and root hydraulic conductivity of container-grown woody plants. J. Amer. Soc. Hort. Sci. 113:138-146.

Nichols, T.J. and A.A. Alm. 1983. Root development of container-reared, nursery-growth, and naturally regenerated pine seedlings. Can. J. For. Res. 13:239-245.

Ruter, J.M. 1993. Growth and landscape performance of three landscape plants produced in conventional and pot-in-pot production systems. J. Environ. Hort. 11:124-127.

Ruter, J.M. 1994. Growth responses of four vigorous-rooted tree species in cupric hydroxidetreated containers. HortScience 29:1089.
Ruter, J.M. and H. Van de Werken. 1988. Solar exposure and rooting of container-grown plants. Amer. Nurseryman 167:121.

Stone, E.C. and E.A. Norberg. 1978. Containerinduced root malformation and its elimination prior to planting. Proc. of the Root Form of Planted Trees Symp. British Columbia Ministry of Forest/Canadian For. Serv. p. 65-72.

Struve, D.K. 1993. Effect of copper-treated containers on transplant survival and regrowth of four tree species. J. Environ. Hort. 11:196-199.

Tilt, K., D. West, B. Goff, and J. Olive. 1993. Summary of evaluation of new containers for nursery production. Comb. Proc. Intl. Plant Prop. Soc. 43:369-371.

Verma, B.P. 1984. Container design for reducing root zone temperature. Proc. Southern Nurserymen's Assn. Res. Conf. 24:179-182.

Whitcomb, C.E. 1981. A vertical-air-root-pruning container. Proc. Intl. Plant Prop. Soc. 31:591597.

Whitcomb, C.E. 1984. Plant production in containers. Lacebark, Chicago.

Whitcomb, C.E. and J.D. Williams. 1985. Stair-step container for improved root growth. HortScience 20:66-67.

Williams, J.D., D.C.Fare, C.H. Gilliam, G.J. Keever, H.G. Ponder, and J.T. Owen. 1993. Shade trees for the southeastern United States. Brown Printing, Montgomery, Ala. 